Florence N. Schleich and Renaud Louis

Dept of Pulmonary Medicine, CHU Sart-Tilman, Liege, I ${ }^{3}$ GIGA Research Group, University of Liege, Liege, Belgium.

Correspondence: Florence N. Schleich, Respiratory Medicine, CHU Sart-Tilman B35, 4000 Liege, Belgium.

E-mail: fschleich@chu.ulg.ac.be

Received: June 272014 | Accepted: July 012014

Conflict of interest: Disclosures can be found alongside the online version of this article at erj.ersjournals.com

\title{
References
}

1 Schleich FN, Chevremont A, Paulus V, et al. Importance of concomitant local and systemic eosinophilia in uncontrolled asthma. Eur Respir J 2014; 44: 97-108.

2 Haldar P, Pavord ID, Shaw DE, et al. Cluster analysis and clinical asthma phenotypes. Am J Respir Crit Care Med 2008; 178: 218-224.

3 Van Den Berge M, Meijer RJ, Kerstjens HA, et al. $\mathrm{PC}_{20}$ adenosine $5^{\prime}$-monophosphate is more closely associated with airway inflammation in asthma than $\mathrm{PC}_{20}$ methacholine. Am J Respir Crit Care Med 2001; 163: 1546-1550.

4 Louis R, Sele J, Henket M, et al. Sputum eosinophil count in a large population of patients with mild to moderate steroid-naive asthma: distribution and relationship with methacholine bronchial hyperresponsiveness. Allergy 2002; 57: 907-912.

5 Kulkarni NS, Hollins F, Sutcliffe A, et al. Eosinophil protein in airway macrophages: a novel biomarker of eosinophilic inflammation in patients with asthma. J Allergy Clin Immunol 2010; 126: 61-69.

6 Pavord ID, Brightling CE, Woltmann G, et al. Non-eosinophilic corticosteroid unresponsive asthma. Lancet 1999; 353: 2213-2214.

7 Green RH, Brightling CE, Woltmann G, et al. Analysis of induced sputum in adults with asthma: identification of subgroup with isolated sputum neutrophilia and poor response to inhaled corticosteroids. Thorax 2002; 57: 875-879.

8 Chung KF, Wenzel SE, Brozek JL, et al. International ERS/ATS guidelines on definition, evaluation and treatment of severe asthma. Eur Respir J 2014; 43: 343-373.

9 Gibson PG. Why inflammatory phenotyping is necessary for successful drug evaluation in asthma and COPD. Eur Respir J 2013; 42: 891-892.

10 Pavord ID, Korn S, Howarth P, et al. Mepolizumab for severe eosinophilic asthma (DREAM): a multicentre, double-blind, placebo-controlled trial. Lancet 2012; 380: 651-659.

\section{Manuscript cited in "Specific inhalation challenge in the diagnosis of occupational asthma: consensus statement"}

\author{
To the Editor:
}

On page 1579 of the manuscript entitled "Specific inhalation challenge in the diagnosis of occupational asthma: consensus statement", a consensus statement published in the June 2014 issue of the European Respiratory Journal, it is stated: "...the duration of exposure should preferably be increased from one day to the next with, for instance, a cumulative exposure limited to $<30 \mathrm{~min}$ on the first challenge day," after which reference numbers 11,13 and 57 are cited [1].

I am the co-author of reference 11 and in this text we say, in table 2 (page 234), to limit exposure to $1 \mathrm{~min}$ on the first day, $5 \mathrm{~min}$ on the second day and $30 \mathrm{~min}$ on the third day [2].

So, our reference was wrongly quoted. Exposing subjects for $30 \mathrm{~min}$ on the first day can lead to severe reactions, which can explain the relatively high frequency of such reactions as referred to in the paper referenced as $57[3]$.

Jean-Luc Malo

Université de Montréal, Dept of Chest Medicine, Hôpital du Sacré-Coeur de Montréal, Montreal, Canada.

Correspondence: Jean-Luc Malo, Université de Montréal, Dept of Chest Medicine, Hôpital du Sacré-Coeur de Montréal, 5400 West Gouin, Montreal, Quebec H4J 1C5, Canada.

E-mail: malojl@meddir.umontreal.ca

Received: June 042014 | Accepted: June 122014

Conflict of interest: None declared. 


\section{References}

1 Vandenplas O, Suojalehto H, Aasen TB, et al. Specific inhalation challenge in the diagnosis of occupational asthma: consensus statement. Eur Respir J 2014; 43: 1573-1587.

2 Vandenplas O, Cartier A, Malo JL. Occupational challenge tests. In: Bernstein IL, Chan-Yeung M, Malo JL, et al., eds. Asthma in the Workplace. 3rd Edn. New York, Taylor and Francis, 2006; pp. 227-252.

3 Vandenplas O, D'Alpaos V, Evrard G, et al. Incidence of severe asthmatic reactions after challenge exposure to occupational agents. Chest 2013; 143: 1261-1268.

Eur Respir J 2014; 44: 1099-1100 | DOI: 10.1183/09031936.00102614 | Copyright @ERS 2014

From the authors:

On behalf of our Task Force, I would apologise for "inappropriately" referencing the quoted article coauthored by Jean-Luc Malo, which was published in his highly renowned textbook Asthma In the Workplace [1]. Actually, we referred to this article because this expert investigator was the first to outline the need to gradually increase the exposure to low-molecular weight agents on consecutive days, mainly to avoid the occurrence of severe delayed asthmatic reactions. Nevertheless, the same sentence also refers to the recent paper by VANDENPLAS et al. [2] who reported a 3\% incidence rate of severe asthmatic reactions recorded during 335 specific inhalation challenges with occupational agents. The result of this retrospective analysis showed that only one severe reaction was delayed and that more than half of the severe reactions developed within the first $30 \mathrm{~min}$ of exposure. These findings indicated that the cumulative duration of exposure to low-molecular weight agents could be safely limited to $15-30 \mathrm{~min}$ on the first challenge day rather than $1 \mathrm{~min}$ on the first day, $5 \mathrm{~min}$ on the second day and $30 \mathrm{~min}$ on the third day as initially proposed by Jean-Luc Malo.

Olivier Vandenplas ${ }^{1}$ and Hille Suojalehto ${ }^{2}$ on behalf of the ERS Task Force on Specific Inhalation

${ }^{1}$ Dept of Chest Medicine, Mont-Godinne Hospital, Universite Catholique de Louvain, Yvoir, Belgium. ${ }^{2}$ Occupational Medicine Team, Finnish Institute of Occupational Health, Helsinki, Finland.

Correspondence: Oliver Vandenplas, Dept of Chest Medicine, Centre Hospitalier Universitaire de Mont-Godinne, Université catholique de Louvain, Av. G. Thérasse, 1-5530 Yvoir, Belgium. E-mail: olivier.vandenplas@uclouvain.be

Received: June 122014 | Accepted: June 162014

Conflict of interest: None declared.

\section{References}

1 Vandenplas O, Cartier A, Malo JL. Occupational challenge tests. In: Bernstein IL, Chan-Yeung M, Malo JL, et al., eds. Asthma in the Workplace. 3rd Edn. New York, Taylor and Francis, 2006; pp. 227-252.

2 Vandenplas O, D'Alpaos V, Evrard G, et al. Incidence of severe asthmatic reactions after challenge exposure to occupational agents. Chest 2013; 143: 1261-1268.

Eur Respir J 2014; 44: 1100 | DOI: 10.1183/09031936.00107214 | Copyright @eERS 2014 